Jalan Teuku Umar, Lubuk Baja, Kota Batam-Indonesia Telp. 0778 - 4083113

Email : info@uis.ac.id / uibnusina@gmail.com Website : uis.ac.id

\title{
ANALISIS KINERJA KEUANGAN SEBELUM DAN SESUDAH MERGER PADA SEKTOR PERBANKAN
}

\author{
Hikmah $^{1}$ \\ ${ }^{1}$ Prodi Manajemen, Fakultas Ilmu Sosial dan Humaniora, Universitas Putera Batam, Kota Batam \\ e-mail: hikmahupb@gmail.com
}

\begin{abstract}
This study aims to determine changes in the company's financial performance before and after the case merger in banking companies listed on the Indonesia Stock Exchange. The population in this study were all banking companies that carried out the merger. The sample used was five banking companies that conducted mergers in 2015 to 2019. The technique used in sampling was purposive sampling technique. The data analysis technique used in this research is quantitative analysis to test the differences in financial performance ratios with the Wilcoxon Signed Rank Test. The result have changes in banking companies listed on the Indonesia Stock Exchange between before and after the merger
\end{abstract}

Keywords: Financial Leverage Multiplier, Merger, Net Profit Margin, Return on Assets, Return on Equity

\section{Pendahuluan}

Globalisasi terus terjadi dari masa ke masa yang diikuti dengan proses integrasi internasional menyebabkan perubahan dan perkembangan pertumbuhan dalam perekonomian yang sangat cepat baik di dalam negeri maupun luar negeri. Perbankan salah satu darah dalam perkembangan perekonomian dalam suatu negara, karena berbagai kegiatan dalam perekonomian yang turut berperan adalah perbankan. Namun dalam dunia perbankan paling sering melangsung merger.

Bank merupakan lembaga keuangan yang berurusan langsung dengan alat tukar yang biasa kita sebut dengan uang, terutama yang menyangkut proses penerimaan uang, penyimpanan uang, pengedaran uang, bahkan peminjaman uang. Bank itu sendiri mempunyai peran penting yakni mempertemukan kedua pihak yang memiliki kepentingan yang berbeda dimana satu pihak yang berkelebihan modal dan satu pihak lain yang membutuhkan modal tambahan dengan bank sebagai perantara atau keagenan diantara keduanya.

Beberapa penelitian sebelumnya telah menemukan pengaruh yang timbul dari adanya merger diantara entitas-entitas, antara lain seperti yang telah dilakukan oleh (Gunawan \& Sukartha, 2013), terjadi kenaikan yang signifikan kinerja pasar perusahaan setelah dilakukannya pengabungan usaha (Merger and Acquisitions) akan tetapi tidak berbanding lurus dengan kinerja keuangan perusahaan terbsebut karena tidak terjadi kenaikan yang signifikan seperti yang dialami pada bagian kinerja pasar perusahaan baik sebelum atau setelah adanya Mergers and Acquisitions. (Putri \& Djajanti, 2013) menemukan bahwa sesudah terjadinya Merger and Acquisitions tidak ditemukan disparitas signifikan pada tahun pertama dan 4 tahun setelahnya meskipun terjadi 
perubahan cukup signifikan pada Return On Asset tetapi masih belum mampu ditarik kesimpulan bahwa Merger and Acquisitions memberikan pengaruh kepada kinerja keuangan perusahaan. Berikut data rasio keuangan beberapa Perusahaan terdaftar di Bursa Efek Indonesia.

Tabel 1. Data rasio keuangan beberapa perusahaan terdaftar di Bursa Efek Indonesia yang melakukan merger

\begin{tabular}{clccllc}
\hline No & Bank & Tahun & ROA/\% & ROE/\% & NPM/\% & LM/X \\
\hline \multirow{2}{*}{1 PT IBK Indonesia } & 2015 & 0,16 & 0,89 & 3,15 & 7,54 \\
& Tbk. & 2016 & 0,15 & 0,85 & 2,57 & 7,09 \\
& 2017 & $-0,20$ & $-1,61$ & $-6,53$ & 6,90 \\
& 2018 & $-0,77$ & $-5,84$ & $-23,24$ & 7,79 \\
& 2019 & $-3,87$ & $-20,65$ & $-167,11$ & 5,34 \\
& 2015 & 1,70 & 7,40 & 18,09 & 5,50 \\
& PT Bank Danamon & 2016 & 2,50 & 8,00 & 20,27 & 4,80 \\
Tbk. & 2017 & 3,12 & 10,50 & 27,06 & 4,55 \\
& 2018 & 3,12 & 10,60 & 28,84 & 4,45 \\
& 2019 & 3,00 & 10,30 & 29,09 & 4,26 \\
\hline
\end{tabular}

Data diatas menunjukkan PT. Bank IBK Indonesia Tbk. sejak tahun 2015 sampai 2019 mengalami penurunan untuk rasio Return On Assets, Return on Equity, dan Net Profit Margin. Sedangkan pada rasio Financial Leverage Multiplier terjadi fluktuasi dari tahun ke tahun. Pada tahun 2019 Bank IBK Indonesia Tbk. melakukan merger antara PT Bank Agris Tbk. dengan PT Bank Mitra Niaga Tbk.

Pada PT. Bank Danamon Tbk. Mengalami fluktuasi Return On Assets, Return on Equity, Net Profit Margin dan Financial Leverage Multiplier. Pada tahun 2019 PT. Bank Danamon Tbk. melakukan merger dengan PT Bank Nusantara Parahyangan Tbk.

Berdasarkan uraian diatas, terdapat beberapa identifikasi masalah sebagai berikut: Return On Assets mengalami penurunan setelah dilakukan merger pada perusahaan PT IBK Indonesia Tbk. (2019), PT Bank Danamon Tbk. (2019), Return on Equity mengalami penurunan setelah melakukan merger pada perusahaan PT IBK Indonesia Tbk. (2019), PT Bank Danamon Tbk. (2019), Net Profit Margin mengalami penurunan setelah melakukan merger pada perusahaan PT IBK Indonesia Tbk. (2019) dan PT Bank Woori Saudara Indonesia Tbk.(2015). Financial Leverage Multiplier mengalami penurunan setelah melakukan merger pada perusahaan PT IBK Indonesia Tbk. (2019) dan PT Bank Danamon Tbk. (2019). Berdasarkan uraian diatas, maka Tujuan penelitian ini adalah sebagai berikut: (1) untuk menganalisis perubahan rasio Return On Assets pada perusahaan perbankan sebelum dan sesudah merger, (2). Untuk menganalisis perubahan rasio Return on Equity pada perusahaan perbankan sebelum dan sesudah merger, (3) Untuk menganalisis perubahan rasio Net Profit Margin pada perusahaan perbankan sebelum dan sesudah merger, (4) untuk menganalisis perubahan rasio Financial Leverage Multiplier pada perusahaan perbankan sebelum dan sesudah merger? 


\section{Kajian Pustaka / Kajian teori Teori Du Pont System}

Du Pont System adalah ROI yang dihasilkan melalui perkalian antara keuntungan dari komponen-komponen sales serta efisiensi penggunaan total asset didalam menghasilkan keuntungan tersebut (Syamsuddin, 2009:64). Du pont Analysis merupakan rasio keuangan yang dapat digunakan untuk melakukan analisis kemampuan perusahaan untuk meningkatkan pengembalian atas ekuitas, atau Return on Equity (ROE). Du Pont dapat dikatakan sebagai sebuah penganalisisan berstruktur untuk semua laporan keuangan yang dijadikan sebagai pengukuran perihal keuangan perusahaan. Du Pont sendiri berguna untuk melakukan analisis rasio profitabilitas dan ROE pada sebuah entitas. Du Pont juga berperan dalam melakukan analisis laporan keuangan perusahaan serta menelaah posisi keuangan pada periode tertentu dengan melakukan penggabungan laporan laba rugi dan laporan posisi keuangan yang menghasilkan rasio profitabilitas yang didalamnya terdapat Return On Total Asset (ROA) dan Return On Equity (ROE).

\section{Bank}

Secara umum, masyarakat mengenal bank sebagai perusahaan atau entitas yang menjalankan kegiatan usahanya dalam bidang keungan dengan menyediakan pelayanan bagi pihak-pihak yang akan melakukan penghimpunan dana dalam bentuk simpanan maupun surat-surat berharga lainnya. Seperti yang tercantum dalam UU RI No. 10 Tahun 1998 yang diterbitkan pada 10 November 1998 tentang Perbankan, bank ialah lembaga resmi negara yang memobilisasi uang dari pihak-pihak dengan berbagai bentuk baik tunai maupun hutang piutang yang berguna untuk menimbulkan terjadinya peningkatan kualitas hidup lapisan masyarakat. Dari beberapa definisi yang telah dipaparkan, ditarik sebuah kesimpulan yakni bank ialah entitas yang bergerak pada industri keuangan sehingga perusahaan perbankan otomatis mengurusi hal-hal yang berhubungan dengan keuangan. Kepercayaan dari masyarakat memicu pihak-pihak untuk mempercayakan dana atau modal yang mereka miliki untuk disimpan pada bank tersebut dan bank juga mendapat pendaan dari dana atau modal yang dimiliki pihak tersebut.

\section{Penggabungan Usaha}

Merger, konsolidasi, dan akuisisi merupakan bagian dari sebuah penggabungan usaha. Merger ialah situasi bergabungnya minimal dua entitas yang saling sepakat kemudian menggunakan nama dari salah satu entitas yang melakukan penggabungan tersebut. Lain halnya dengan konsolidasi, konsolidasi memiliki definisi yakni situasi bergabungnya minimal dua entitas yang saling sepakat kemudian menghasilkan nama baru entitas meninggalkan nama lama entitas yang melakukan penggabungan tersebut. Sedangkan Akuisisi dapat diartikan sebagai situasi bergabungnya minimal dua entitas yang saling sepakat kemudian salah satu entitas (pengakuisisi) memiliki hak dan wewenang untuk mengendalikan entitas yang diakuisi. Merger and Acquisitions dinilai baik dan paling efisien jika dilihat dari perkembangan perekonomian yang terjadi dikarenakan mampu mencapai konsep profitabilitas yakni akuisisi strategi guna membuat peningkatan sinergisme yang meminimalisir resiko dan akuisisi finansial guna memperoleh laba seperti yang telah ditargetkan perusahaan (Heykal \& Wijayanti, 2015), (Kasmir, 2014). 


\section{Laporan Keuangan}

Mulai dari organisasi berskala kecil hingga orgranisasi berskala besar memiliki laporan keuangan dimana laporan tersebut berisi posisi keuangan yang selama ini telah dilakukan oleh perusahaan melalui kegiatan operasional. Laporan keuangan dapat dikatakan sebagai embaran yang memberikan gambaran atas posisi entitas tersebut dan dijadikan dasar pengambilan keputusan atas hasil kerja operasional entitas". Terdapat banyak gambaran tentang perusahaan terutama bagaimana kondisi keuangan saat ini, bagaimana hasil dari operasional yang dilakukan selama periode tertentu, dan kemungkinan yang akan terjadi ke depannya.

\section{Kinerja Keuangan}

Kinerja keuangan merupakan prospek atau masa depan, pertumbuhan, dan potensi perkembangan yang baik bagi perusahaan. Informasi Kinerja keuangan sangatlah diperlukan dalam menilai perubahan potensial sumber daya ekonomi untuk memprediksi kapasitas produksi dari sumber daya yang tersedia. Kinerja keuangan biasanya digunakan oleh perusahaan untuk pengambilan keputusan-keputusan penting, namun sebelumnya harus dilakukan yang namanya analisis rasio keuangan terhadap data keuangan perusahaan yang sebelumnya telah dicatat sesuai dengan ketentuan prinsip akuntansi yang berlaku (Eprilia \& Siregar, 2020). Kinerja keuangan sendiri memiliki peran penting untuk memberikan penilaian atas perubahan-perubahan faktor produksi moneter dalam upaya pengendalian dikemudian hari serta melakukan prediksiprediksi produktivitas potensial yang berasal dari faktor produksi yang dimiliki.

\section{Rasio Keuangan}

Rasio keuangan yang dipakai untuk melakukan penganalisisan atas kinerja keuangan perusahaan perbankan dari sebelum dan sesudah dilakukannya merger adalah analisis Du Pont, antara lain seperti dibawah ini:

\section{Net Profit Margin (NPM)}

Dapat dikatakan sebagai skala perbandingan untuk memberikan gambaran derajat surplus dari hasil operasional bank kemudian dibandingkan dengan kegiatan yang dapat dianggap sebagai pendapatan selama bank beroperasional dalam satu periode tertentu. Makin tinggi hasil yang ditunjukkan dari rasio ini, dapat dikatakan kinerja keuangan makin potensial, hal ini terlihat dan sangat ditentukan dari tingginya profit yang didapat pada periode tersebut. Rasio ini dirumuskan sebagai berikut:

\section{Financial Leverage Multiplier (FLM)}

$$
\mathrm{NPM}=\frac{\text { Earning After Tax }}{\text { Sales }} \times 100
$$

Rasio Financial Leverage Multiplier lebih dikenal dengan nama rasio pengganda utang keuangan. Rasio ini dapat dirumuskan sebagai berikut:

\section{Return on Assets (ROA)}

$$
\mathrm{FLM}=\frac{\text { Total Assets }}{\text { Total Equity }}
$$

Return on Assets sendiri ialah skala perbandingan yang mampu memberikan pengukuran atas kapasitas pihak penanggung jawab entitas menghasilkan laba dan manajerial efisiensi secara menyeluruh (Kasmir, 2008). Bank Indonesia mempunyai parameter tersendiri dalam menilai Return on Assets yakni berada pada kisaran $0.5 \%$ - 
1,25\% yang tertuang dalam Peraturan Bank Indonesia No: 6/10/PBI/ 2004. Rasio ini dirumuskan sebagai berikut:

\section{Return on Equity (ROE)}

$$
\mathrm{ROA}=(N P M \times T A T O) \times 100 \%
$$

Return on Equity ialah skala perbandingan yang diciptakan dalam rangka mengukur kapabilitas pihak manajemen bank yang dilihat dari pengelolaan modal dalam upaya memperoleh pendapatan bersih (Kasmir, 2008). Rasio ini dirumuskan sebagai berikut:

$$
\mathrm{ROE}=(R O A \times F L M) \times 100 \%
$$

\section{Hipotesis}

Berdasarkan latar belakang masalah, rumusan masalah dan tujuan penelitian yang telah dijelaskan sebelumnya, maka hipotesis dalam penelitian ini adalah:

1. H1:Terdapat perubahan Return on Assets pada perusahaan perbankan yang terdaftar di Bursa Efek Indonesia antara sebelum dan sesudah melakukan merger.

2. H2:Terdapat perubahan Return on Equity pada perusahaan perbankan yang terdaftar di Bursa Efek Indonesia antara sebelum dan sesudah melakukan merger.

3. H3:Terdapat perubahan Net Profit Margin pada perusahaan perbankan yang terdaftar di Bursa Efek Indonesia antara sebelum dan sesudah melakukan merger.

4. H4:Terdapat perubahan Financial Leverage Multiplier pada perusahaan perbankan yang terdaftar di Bursa Efek Indonesia antara sebelum dan sesudah melakukan merger.

\section{Metode Penelitian}

Populasi dalam penelitian ini ialah laporan keuangan perusahaan perbankan yang terdaftar di Bursa Efek Indonesia tahun 2015 - 2019 yakni meliputi 45 perusahaan yang bergerak dalam bidang perbankan. Sampel yang diambil oleh peneliti dan dihimpun melalui proses penggunaan metode Purposive Sampling. Purposive Sampling yakni metode pemungutan representatif memakai penentuan persyaratan. Persyaratan yang di tentukan oleh peneliti atas berbagai pertimbangan yakni seperti bawah ini:

1. Perusahaan perbankan yang terdaftar di Bursa Efek Indonesia.

2. Laporan keuangan perusahaan telah diaudit.

3. Memiliki laporan keuangan dari tahun 2015 sampai dengan tahun 2019.

4. Perusahaan perbankan yang melakukan merger dalam tahun 2015 sampai 2019.

Dengan persyaratan diatas maka perusahaan perbankan yang sesuai kondisi sebagai representatif riset ini sebanyak 5 entitas perbankan.

\section{Hasil dan Pembahasan}

Data yang digunakan dalam penelitian ini adalah data laporan keuangan perusahaan yang melakukan merger pada periode pengamatan dari tahun 2010-2019. Sumber data diperoleh dari Bursa Efek Indonesia. Selain itu, terdapat juga beberapa data yang diperoleh melalui website masing-masing perusahaan yang melakukan 
merger. Penelitian ini membandingan rasio keuangan antara sebelum melakukan merger dengan sesudah melakukan merger. Rasio-rasio keuangan yang digunakan dalam penelitian ini, yakni ROA, ROE, NPM, dan FLM.

Setelah mengetahui rasio masing-masing perusahaan, selanjutnya masingmasing rasio dari kelima perusahaan akan dibandingkan antara periode sebelum dan sesudah akuisisi. Lalu peneliti akan menjabarkan statistik deskriptif dari tiap rasio. Setelah itu, penelitian dilanjutkan dengan melakukan pengujian hipotesis menggunakan statistik non parametrik untuk sampel yang berpasangan dengan uji Wilcoxon Signed Rank Test dan taraf signifikansi 5\% dan $10 \%$.

Uji peringkat tanda Wilcoxon digunakan untuk mengevaluasi perlakuan (treatment) tertentu pada dua pengamatan,antara sebelum dan sesudah adanya perlakuan tertentu. Uji ini menguji hipotesis h1 sampai h8, dengan mengunakan tingkat signifikasi $\alpha=5 \%$, maka jika prob $<$ taraf signifikansi yang telah ditetapkan $\alpha=5 \%$, maka variable independen tersebut berpengaruh siginifikam terhadapa variabel dependen, berarti terdapat perbedaan yang secara statistik signifikan masing-masing rasio keuangan anatar sebelum dan sesudah merger dan akuisisi. Berikut merupakan hasil Wilcoxon Signed Ranks Test.

Tabel 2. Hasil Pengujian Wilcoxon Signed Ranks Test

Test Statistics ${ }^{\mathrm{a}}$

\begin{tabular}{|c|c|c|c|c|}
\hline & $\begin{array}{l}\text { ROA_SETELAH } \\
\text { ROA_SEBELU } \\
\text { M }\end{array}$ & $\begin{array}{l}\text { ROE_SETELAH } \\
\text { ROE_SEBELU } \\
\text { M }\end{array}$ & $\begin{array}{l}\text { NPM_SETELAH } \\
\text { NPM_SEBELU } \\
\text { M }\end{array}$ & $\begin{array}{l}\text { FLM_SETELAH } \\
\text { FLM_SEBELU } \\
\text { M }\end{array}$ \\
\hline $\mathrm{Z}$ & $-2.537^{b}$ & $-3.928^{b}$ & $-.221^{\mathrm{c}}$ & $-4.371^{b}$ \\
\hline $\begin{array}{l}\text { Asymp } \\
\text {. Sig. } \\
(2- \\
\text { tailed })\end{array}$ & .017 & .000 & .781 & .000 \\
\hline $\begin{array}{l}\text { a. V } \\
\text { b. Base } \\
\text { c. Base }\end{array}$ & $\begin{array}{l}\text { lcoxon Signed Ran } \\
\text { on positive ranks. } \\
\text { on negative ranks. }\end{array}$ & s Test & & \\
\hline
\end{tabular}

Berdasarkan hasil pengujian diatas yaitu nilai $\mathrm{p}$ sebesar 0.017 berarti $\mathrm{p} \leq 0.05$. Maka H1 diterima yaitu terdapat perubahan Return on Assets pada perusahaan perbankan yang terdaftar di Bursa Efek Indonesia antara sebelum dan sesudah melakukan merger.Berdasarkan hasil pengujian diatas yaitu nilai p sebesar 0.000 berarti $\mathrm{p} \leq 0.05$. Maka H2 diterima yaitu terdapat perubahan Return on Equity pada perusahaan perbankan yang terdaftar di Bursa Efek Indonesia antara sebelum dan sesudah melakukan merger.

Berdasarkan hasil pengujian diatas yaitu nilai $\mathrm{p}$ sebesar 0.781 berarti $\mathrm{p} \geq 0.05$. Maka H3 ditolak yaitu tidak terdapat perubahan Net Profit Margin pada perusahaan perbankan yang terdaftar di Bursa Efek Indonesia antara sebelum dan sesudah melakukan merger. Berdasarkan hasil pengujian diatas yaitu nilai $\mathrm{p}$ sebesar 0.000 berarti $\mathrm{p} \leq 0.05$. Maka H4 diterima yaitu terdapat perubahan Financial Leverage Multiplier pada perusahaan perbankan yang terdaftar di Bursa Efek Indonesia antara sebelum dan sesudah melakukan merger. 


\section{Pembahasan}

Berdasarkan akhir pengujian hipotesis menunjukkan Return on Assets (0.017), Return on Equity (0.000) dan Financial Leverage Multiplier (0.000) memiliki angka p lebih kecil daripada 0.05 maka memiliki perubahan pada perusahaan perbankan yang terdaftar di Bursa Efek Indonesia antara sebelum dan sesudah melakukan merger. Sedangkan Net Profit Margin (0.781) yang memiliki nilai p lebih besar daripada 0.05 tidak memiliki perubahan pada perusahaan perbankan yang terdaftar di Bursa Efek Indonesia antara sebelum dan sesudah melakukan merger.

Akhir penelitian ini mendukung penelitian yang dilakukan oleh (Morina, 2018) yang menyatakan Return On Asset (ROA) ada perbedaan antara sebelum dan sesudah merger dan akuisisi pada perusahaan yang terdaftar BEI periode 2013-2015. Penelitian yang dilakukan oleh (Gustina, 2017) yang menyatakan return on equity yang menunjukkan ada perbedaan yang signifikan antara sebelum dan sesudah merger dan akuisisi dan net profit margin tidak menunjukkan adanya perbedaan sebelum dan sesudah merger dan akuisisi dan penelitian yang dilakukan oleh (Esterlina, Firdausi, Administrasi, \& Brawijaya, 2017) juga menunjukkan terdapat perbedaaan yang signifikan pada beberapa rasio keuangan seperti net profit margin dan return on asset.

Pada penelitian ini juga berlawanan dengan penelitian yang dilakukan oleh (Varana et al., 2018) yang menunjukkan tidak ada perbedaan antara kinerja keuangan sebelum dan sesudah akusisi yang diukur dengan return on equity. Penelitian yang dilakukan oleh (Nafilah, 2019) yang menyatakan net profit margin yang digunakan pada penilitian ini, menunjukan adannya perbedaan yang signifikan. Penelitian yang dilakukan oleh (Purnawati, 2016) menyatakan tidak terdapat perbedaan yang signifikan pada kinerja keuangan ROA sebelum dan sesudah akuisisi dan penelitian yang dilakukan oleh (Firdaus \& Dara, 2020) juga menyatakan ROA dan NPM memperoleh hasil yang tidak memiliki perbedaan yang signifikan.

\section{Simpulan dan Saran}

Berdasarkan hasil penelitian dan pembahasan diatas dapat disimpulkan bahwa:

1. Perusahaan perbankan yang melakukan merger mengalami penurunan pada angka ROA.

2. Perusahaan perbankan yang melakukan merger mengalami penurunan pada angka ROE.

3. Perusahaan perbankan yang melakukan merger mengalami kenaikan pada angka NPM.

4. Perusahaan perbankan yang melakukan merger mengalami penurunan pada angka FLM.

\section{Daftar Pustaka}

Banjarnahor, H., \& Lubis, S. H. (2019). Identification of Variables That Improve The Reveneus of Entertainment Tax In The City of Batam City With GRDP Price Apply As Moderating Variable Identification of Variables That Improve The Reveneus of Entertainment Tax In The City of Batam City With GRDP Price Apply As Moderating Variable, (November).

Chandrarin, G. (2017). Metode Riset Akuntansi Pendekatan Kuantitatif (S. Aklia (ed.)). Salemba Empat.

Eprilia, I., \& Siregar, D. L. (2020). Pengaruh Rasio Likuiditas Dan Rasio Aktivitas Terhadap Kinerja Keuangan Perusahaan Manufaktur Di Bursa Efek Indonesia, 
$4(1), 160-170$.

Esterlina, P., Firdausi, N. N., Administrasi, F. I., \& Brawijaya, U. (2017). Analisis kinerja keuangan perusahaan sebelum dan sesudah merger dan akuisisi, 47(2).

Firdaus, G. R., \& Dara, S. R. (2020). Analisis perbandingan kinerja keuangan sebelum dan sesudah melakukan akuisisi dan merger pada perusahaan non keuangan, 2(2), $63-74$.

Gunawan, K. H., \& Sukartha, I. M. (2013). Kinerja Pasar Dan Kinerja Keuangan Sesudah Merger Dan Akuisisidi Bursa Efek Indonesia.

Gustina, I. R. A. (2017). Analisis Kinerja Keuangan Sebelum Dan Sesudah Merger Dan Akuisisi Pada Perusahaan Yanggo Public Yang Terdaftar Di Bei, 6, 1-23.

Heykal, M., \& Wijayanti, M. H. (2015). Analisis Hubungan antara Merger dan Akuisisi Terhadap Kinerja Keuangan dan Return Saham pada Perbankan yang Terdaftar di BEI.

Meta, A. (2010). Analisis Manajemen Laba dan Kinerja Keuangan Perusahaan Pengakuisisi Sebelum dan Sesudah Merger dan Akuisisi yang Terdaftar di Bursa Efek Indonesia Tahun 2008-2009.

Morina, T. (2018). Perusahaan Sebelum Dan Sesudah Merger Dan Akuisisi ( Studi Perusahaan Yang Melakukan Merger Dan Akuisisi Yang Terdaftar Di Bei 2013$2015), 1(1), 71-85$.

Nafilah, A. (2019). Melakukan Merger Dan Akuisisi ( Studi Pada Perusahaan Yang Terdaftar Pada Bei Dan Melakukan Merger Dan Akuisisi Pada Periode 2012-2014 ), 72(1).

Purnawati, N. K. (2016). Analisis Kinerja Keuangan Perbankan Sebelum Dan Sesudah Akuisisi Pada Bank Sinar Bali, 5(6), 3504-3531.

Putra, A. (2014). Analisis Perbandingan Kinerja Keuangan Sebelum dan Sesudah Merger Tahun 2008 (Studi Kasus pada Bank CIMB Niaga Periode Tahun 20032013).

Sugiyono. (2012). Metode Penelitian Kuantitatif, Kualitatif, Dan $R \& D$ (Lima Belas). Bandung: ALFABETA.

Varana, C. J., Rusliati, E., Ekonomi, F., \& Pasundan, U. (2018). Akuisisi Pada Pt Bumi Serpong Damai Tbk, 11(1), 44-50. 